5 По данным Госдепартамента США и американского проф. Дендерфильда, сенат США с 1789 г. по 1934 г. из представленньх ему для одобрения 962 договоров отклонил или притормозил так или иначе 280; при этом 15 договоров были отклонены пюлностью и 173 приняты с изменениями, что повлекло в 48 случаях отказ контрагента.

б По фамилии заключавшего их со стороны Мексики министра иностранньх дел.

7 За первые полвека существования Соединенньг Штатов Америки таких договоров было заключено 349 с получением так называемой сенатской ратификации.

8 Заметим в числе этих соглашений исторически интересное - протокол от 23 сентября 1915 r. с Росскей о разрешении вывоза из России в США товаров, ранее подпадавших под военное эмбарго.

${ }^{9}$ См. Ш у р, Дигесты международного права, т. V, с. 215

10 Таможенный и патентный суд США в делах Флетчера (1937 г.) и Уислера (1938 г.) признал себя некомпетентным обсуждать вопрос о конституционности торговьх соглашений президента. Я не останавливаюсь поэтому на его практике.

11 См. выдержки из решения в “Колумбийском юридическом обозрении” 1942, май, т. 42, № 5, с. 837 и 841.

12 Дело Хаунштен против Лингама (1879 r. наследование), Асакура против Ситл (1924 г., профессия), Джордон против Таширо (1928 г., приобретение собственности). См. Чарльс Герстенберг, Американское конституционное право, 1937, с. 48 (на англ. яз.).

${ }^{13}$ См. дела Миссури против Голланда (1920 г.), Тодок против банка США (1930 г.), там же

- 14. См. “Колумбийское юридическое обозрение”, 1942, № 5 с. 842.

Статья поступила в редакцию от профессора Лазарева М.И. в июне 1999 г.

\title{
НОВАЯ СТРАТЕГИЧЕСКАЯ КОНЦЕПЦИЯ НАТО, ВОЕННАЯ АКЦИЯ АЛЬЯНСА ПРОТИВ СРЮ И МЕЖДУНАРОДНЫЙ ПРАВОПОРЯДОК (Дискуссия на кафедре международного права МГИМО (У) МИД РФ)
}

\section{Профессор В.А. Романов}

Свое пятидесятилетие Североатлантический альянс отметил под несколько помпезным девизом: "НАTO XXI века берет начало сегодня: новые миссии, новые члены и новые партнеры." Здесь не упоминается новая Стратегическая концепция, принятая на юбилейном саммите альянса в апреле 1999 г. Это однако не означает, что концепция не заслуживает самого пристатьного внимания, и прежде всего, с точки зрения ее соотношения с существующими в мире реальностями, включая сложившийся международный правопорядок.

Для Стратегической концепции НАТО характерно то, что вьдвигая далеко идущие военно-политические установки для деятельности союза в предстоящие годы, она пьтается сконструировать для них и некие особые международно-правовые, а то и квази-международно-правовые параметры. 
В Концепции это достигается тем, что ее установки затрагивают не только договор 1949 г., на котором основывается функционирование альянса - Североатлантический пакт 1949 г., ныне все чаще называемый Вашингтонским договором, - и де-факто вносят в него немалые коррективы, а плавное, во многом посягают на сложившийся на протяжении более чем полстолетия международньй правопорядок и его договорную основу, воплощенную прежде всего в Уставе ООН.

На содержании Концепции в немалой степени сказалось то обстоятельство, что ее разработка совпала с подготовкой в кругах НАТО военной акщии против СРЮ, а окончательную доводку концепщия проходила в условиях, когда эта акция началась и приобрела достаточно масштабный характер. Многие положения Концепции предстают поэтому как попьтка обоснования предпринятъх НАТО военньх мер на Бапканах, и возфедения возможности тақого рода действий в правило, в некую новую модель дальнейшей политики и практики альянса, а в целом - как далеко идущие притязания на якобы особые рољ и место НАТО в системе современного межлународного правопорядка. На содержании Концепции не могли, конечно, не сказаться и разногласия между членами НАТО, главным образом США и Англией, с одной стороны, и другими ведущими европейскими членами союза, в том числе и по международно-правовьм параметрам, как это показал проводившийся под эгидой американской ассоциации ООН и Фонда Карнеги, Кругльй стол (анализ разногласий по этим параметрам дан в разработке "NATO, the UN, and the Use of Force", by Ivo H. Daalder, Brookings Institution).

1. Безосновательные претензии с опорой на силу.

Рассматривая международно-правовую сторону дела, следует прежде всего отметить, что само по себе наличие в рамках международного правопорядка договора между группой государств о коллективной обороне, каким с момента своего зактючения преподносит себя пакт НАТО, не является чем-то таким, что могло бы оправдывать такого рода притязания. В мире имеются и другие договоры военно-политического характера, объединяющие узкие группы государств и содержащие сопоставимые обязательства, в сфере безопасности. Достаточно сослаться на существуюший в Европе с 1948 г. (частично изменен в 1954 г.) Брюссельский договор, предусматривающий, наряду с экономическим и культурньм сотрудничеством, каллективную оборону в случае вооруженного нападения на его участников и являюшийся правовой основой ЗЕС, с окончанием "холодной войны" и затуханием конфронтации Восток-Запад этот союз встал на путь реацистического переосмысливания своего места в преодолевающей раскол Европе.

Иное дело НАТО. После прекращения существования ее военно-политического антагониста - Варшавского договора, а затем и с распадом СССР, казалось, догжны были отпасть мотивы для военного активизма Североатлантического альянса, и на римском саммите НАТО в 1991 г. были предпринят ряд мер, в итоге которьх и ныне алянс подтверждает в Концепции, что "не считает себя противником какой бы то ни было страны". Элементарный здравый смысл и логика требовали бы завершить это положение признанием того, что тем самым исчерпьвается и военная заостренность механизма НАТО. Однако Концепция показьдает, что военной машине альянса уготовано еще более претенциозное, да и опасное, чем ранее, предназначение. Рождается новая Европа, и при этом развертывается евроатлантическая структура безопасности, “основу которой составляет НАТО", - возвещается в Концепции. Тем самым НАТО, состоящая из 19 государств, претендует на то, чтобы быть основой безопасности на континенте, где уже функционирует Организация по безопасности и сотрудничеству в Европе, охватывающая 50 с лишним стран. Невольно создается представление, что лишившись военного противника в регионе, НАТО видит в ОБСЕ своего политического если не антипода, то соперника, стремится отодвинуть эту общеевропейскую структуру на задний план, расширяя при этом возможности шия своего военного активизма. 
2. Нарушения принцпа неприменения сиљы и попьтки деформирования института самообороны через самоприсвоение права действовать вне рамок статьи 5 договора НАТО.

Подобное, своего рода двойное, посягательство - на общий международный правопорядок и на основы общеевропейской безопасности - в Стратегической концепции НАТО осуществляется прежде всего в вопросе об использовании вооруженной силы для действий против других государств.

На рубеже тысячелетий, после пройденного человечеством опьта войн и конфликтов, казалось бы излишним напоминать, что применение силы, и прежде всего вооруженной, одним государством или группой государств против друтого - запрещено, если речь не идет о мерах законной самообороны в ответ на вооруженное нападение или об участии в санкция по решению Совета Безопасности ООН. Именно эти положения выражены в статьяХ 2 (п. 4), 39, 42 и 51 Устава $\mathrm{OOH}$ и в формуле принципа неприменения силы, содержащейся в Хельсинкском заключительном акте, да и в самом Вашингтонском договоре.

O том, что запрет на применение силы носит характер императивной нормы международного права, т.е. правила, которое признается международньм сообществом в целом как норма, отклонение от которой недопустимо. Соединенным Штатам, лидирующим в военной акции против Югославии, известно как никому другому. На императивный характер такого запрета указал Международный суд ООН в своем решении, вынесенном против США в 1986 г. по жалобе Никарагуа по поводу американских военньх происков против этого государства.

Нарушение этой императивной нормы квалифицируется в международном праве как акт агрессии - и не только согласно Определению агрессии, принятому ООН в 1974 г., где в числе актов агрессии указывается "бомбардировка вооружёньми силами государства территории другого государства". Уместно напомнить, что сами США еще в 1945 г. при разработке Устава Международного Нюрнбергского военного трибунала предусмотрели в перечне действий, составляющих "преступление агрессии", такой акт как "нападение наземньх, военноморских и военно-воздушных сил, хотя бы и без объявления войны, на территорию, суда или самолеты другого государства".

Стратегическая концепция трактует полномочия НАТО и участвующих в альянсе стран на применение вооруженной силы против других государств, как если бы все эти постулаты международного и общеевропейского правопорядка бълии в состоянии отмирания либо накануне упразднения.

Упомянув о том, что действия альянса в случае вооруженного нападения предусматриваются статьями 5 и 6 Вашингтонского договора, Концепция заявляет, что отныне альянс привержен некоему широкому подходу к проблеме безопасности, одним из проявлений чего является "эффективное реагирование на кризисные ситуации”, “в том числе путем осуществления операций, не предусмотренных статъей 5 ", иначе говоря, военных мер, не имекщих чего-либо общего с самообороной или санкциями по Уставу ООН.

На проведении таких операций в Концепции делается едва ли не больший акцент, чем непосредственно на обороне от реального нападения. Операции не предусмотренные статьей 5, "могут оказаться такими же насущно необходимыми, как решение некоторьх задач в области коллективной обороны", - подчеркивается в Концепции.

Чтобы максимально расширить возможность военньг мер вне рамок этой статьи, их конкретные основания прописаны в Концепции настолько широко и неопределенно, что к числу рисков для безопасности и стабильности в Евроатлантическом регионе и вокрут него отнесены и региональные кризисы "на периферии альянса", а равно "этническая и политическая вражда, территориальные споры, неадекватные или неудачные попытки реформ, нарушения прав 
человека и распад государств". Попросту говоря, все аномальные явления, свойственные переходному - от биполярности к новой модели международньх отношений - периоду трактуются в Концепции как факторы, могущие обуславливать военно-силовое реагирование со стороны НАТО.

А в изложении еще более конкретньх по существу casus belli Концепция вообще утрачивает чувство меры: заявляется, что “интересам безопасности союза может угрожать более широкий” (чем вооруженное нападение) круг явлений, в том числе терроризм, саботаж и организованная преступность, а также перебои в поставке жизненно важньх ресурсов" и даже "неконтролируемое перемещение огромньх масс людей, особенно в результате вооруженных конфликтов".

Нельзя не заметить, что для россиян в ряде этих положений весьма узнаваемо, кто и что может стать объектом такого реагирования, да и вообще не так уж много найдется в мире государств, которые не сталкивались бы с подобного рода проблемами и тем самым не оказывались бы потенциальными жертвами вооруженньх акций НАТО, проводимьх вне рамок ст. 5 ее договора, а то и на еще более широком и менее определенном основании - в порядке “реагирования на кризисные ситуации".

Выражаемое этими понятиями нововведение в регламентацию применения вооруженной силы Концепщия сопровождает оговоркой “в соответствии с международным правом", что является передержкой, ибо уже более полувека в международном праве, - как уже указывалось, осуждается и отвергается возможность применения вооруженной силы против государства по такого рода основаниям, не имеющим ничего общего с самообороной или санкцими. Как видно из Декларации принцилов международного права, принятой ООН в 1970 г., за исктючением этих случаев утроза силой или ее применения "является нарушением международного права и Устава ООН"; “они никогда не дагжны применяться в качестве средства урегулирования международньд вопросов".

Но не только в этом дело. Стратегическая концепция НАТО, как видно, прямо деформирует само право государства на индивидуальную или коллективную самооборону, которая Уставом ООН допускается лишь в случае, “если произойдет вооруженное нападение на члена Организации”, и меры осуществления которой "никоим образом не должны затрагивать полномочий и ответственности Совета Безопасности". За расширенную интерпретацию права на индивидуальную и коллективную самооборону еще в ноябре 1998 г. высказалась Североатлантическая Ассамблея, по мнению которой, это право должно "включать защиту общих интересов и ценностей, в том числе в случае, когда последним угрожают гуманитарные катастрофы, преступления против человечности и военные преступления". Не просто отвергая эту трактовку, но и активно возмущаясь ею, проф. Б. Симма, член Комиссии международного права ООН, член консультативного совета по международному праву и делам ООН при МИД Германии, по поводу подобного расширения сферы применения права на самооборону высказался в том плане, что оно “нетерпимо и, конечно, абсурдно с точки зрения правовой и не застуживают дальнейшего комментирования". ("NATO, the UN, and the Use of Force: Legal Aspects").

К этому едва ли можно что добавить.

3. “Гуманитарная интервения" в исполнении военной машины НАТО.

В качестве основания для применения вооруженной силы против третьих государств Стратегическая концепция НАТО поименно не ссылается на допустимость т.н. гуманитарной интервенции, как она признается среди некоторых специалнстов международного права на Западе. Однако в ходе разработки Концепции и особенно в связи с ситуацией в Косово немалый акцент делается на том, что грубые и массовые нарушения прав человека и вообще надвигавшаяся в этом крае гуманитарная катастрофа являются чуть ли не императивным 
основанием для военного вмешательства НАТО, т.е. все той же "гуманитарной интервенции". Да и ряд цитированньх выше положений Концепции по сушеству выражает притязания НАТО на право осуществлять такую интервенцию. Но притязания эти не имеют международно-правовьх оснований.

Посягательства на права человека и принципы гуманности подлежат квалификации как нарушения соответствующих норм международного грава и конкретньх международньх соглашений. Реакция со стороны третьих государств или их организаций не может выходить за пределы того, что называют репрессалиями. Но "государства обязаны воздерживаться от актов репрессалий, связанньх с применением силы" - подчеркивается в Декларации о принципах международного права. Другая стороны дела состоит в том, что "гуманитарная интервенция" вообие не известна как институт позитивного международного права.

Со времени Французской ревалюции 1789 г. и известного послания Президента США Монро 1823 г. относительно невмешательства оно явилось предметом регулирования во многих международньх актах, но ни в одном из них не предусматривалось допустимость “гуманитарной интервенции". Устав ООН, закрепляя принцип невмешательства в дела "по существу входящие во внутреннюю компетенцию любого государства", делает из этого принципа только одно исключение: в случае "применения принудительньх мер на основании главы VII", т.е. по решению Совета Безопасности ООН, а не по собственному усмотрению какого-либо государства, либо их альянса. Концепщия "гуманитарной интервенции” не выдерживает проверки на обоснованность. Это констатировал, в частности МИД Великобритании, который в 1986 г. высказался в том плане, что подавляющее болышинство современных правовьх авторитетов "выступают против существования права на гуманитарную интервенщию” по трем главным основаниям: во-первьх, не представляется, что Устав ООН и в целом современное международное право предусматривают такое право; во-вторьх, практика государств за последние два века и особенно с 1945 г. в лучшем случае знает лишь небольшое число случаев действительно гуманитарной интервенции, а по мнению многих - вообще ни одного; и наконец, масштабы зоупотребления таким правом в сильной мере свидетельствуют против его создания. "Гуманитарные интервенции”, "военный гуманитаризм", как это иногда называют на Западе, включающий угрозу или применение силы без полномочий от Совета Безопасности “будет в принципе оставаться нарушением международного права".

Характерны также соображения, высказывавшиеся в германском бундестаге в октябре 1998 г., когда речь шла лишь об угрозах НАТО в адрес СРЮ. Признавая юридическую уязвимость своей позиции, Правительство ФРГ тем не менее утверждало, что ситуация в Косово настолько отчаянна, что оправдывает эти угрозы, даже без мандата со стороны ООН, “в состоянии гуманитарной необходимости, не оставляющей выбора средств". При этом подчеркивалось, что германское согласие с правовой позицией, занятой альянсом в специфическом случае с Косово, не должно рассматриваться как “зеленый свет" для подобных интервенций вообще. По словам тогдашнего министра иностранньг дел ФРГ Кинкеля, "решение НАТО не должно стать прецедентом"; в том, что касается монополии Совета Безопасности на применение силы “мы должны избежать того, чтобы оказаться на сколъзком склоне".

Таким образом, “гуманитарную интервенцию” с применением военной силы невозможно квалифицировать иначе как вооруженной агрессией. В международном праве, международной практике еще с 30-х годов нынешнего столетия сложился постулат, в силу которого, хак подчеркивается в принятом ООН определении агрессии, “никакие соображения любого характера, будь то политического, экономического, военного или иного характера, не могут служить оправданием агрессии". 
“Агрессия влечет за собой международную ответственность...” Она является международным преступлением. Интервенция, вмешательство во внутренние или внешние дела государств рассматривается в проекте Кодекса преступлений против мира и безопасности человечества, подготовленном по линии ООН, как одно из таких преступлений.

Международная норма непререкаема: “никакие соображения...”, а значит и “гуманитарность" интервенции не может служить ее оправданием. Гуманитарные акции вообще не могут осуществляться антигуманными методами - бомбежками, обстрелами и т.П. методами, применяемыми НАТО против СРЮ.

4. Ставка на расширение пространственной сферы действия альянса.

В процессе разработки Стратегической концепции немалое место занял вопрос о расширении пространственной сферы действия НАТО, каковой согласно Вашингтонского договора является североатлантический регион к северу от тропика Рака.

Напрямую, expressis vertis, концепция говорит о такого рода расширении весьма сдержанно. Однако из ряда ее положений прямо вытекает распространенные сферы действия альянса за пределы обозначенного в договоре региона. Со ссылкой на то, что в договоре предусмотрено отражение нападения на территорию государствучастников “откуда бы оно ни исходило", в Концепции утверждается, что "соображения безопасности аљьяса требуют рассмотрения этого вопроса во всемирном масштабе”. В этой связи Концепция предусматривает, что вооруженные силы атьянса будут выполнять его обязательства по коллективной обороне "и проведению операций в кризисньх ситуациях", возникающих иногда "вдали от районов их обычного расположения, в том числе за пределами территорий стран НАТО”.

Присваивание со стороны НАТО функций борьбы с распространением ядерного, химического и бактериологического оружия особенно выпукло отражает намерение альянса проводить свои действия и в других регионах.

Известно, что хотя проблема нераспространения этих видов оружия по существу носит глобаљньй характер, она едва ли остро стоит в Европе и тем более в Североатлантическом регионе, где, кроме признанньх ядерных держав - России, Англии и Франции, нет других государств, имеющих программы создания ядерного оружия. Следовательно, закрепляемая в Концепции функция НАТО противодействовать распространению ОМУ (оружия массового уничтожения) означает, что альянс имеет в виду распространять свои прерогативы, в том числе в отношении военного противодействия, на другие районы, и это конечно, учитывая складывающиеся реальности, прежде всего Азии.

При всем этом по вопросу о “географической досягаемости” НАТО, ero "радиусе действия", как, впрочем, и по другим подобного рода новациям в сфере военно-политической деятельности НАТО, за положениями Концепции скрываются прежде всего американские замыслы.

С точки зрения США, фундаментальная цель НАТО после "холодной войны” должна сместиться “с защиты общей территории к защите общих интересов членов альянса". Это означает его трансформацию не в некую “глобацьую НАТО", а в "НАТО, которая глобально активна". Вопрос не в том, должен ли альянс "играть роль за пределами Европы, а в том, как далеко за пределы союзной территории его (альянса) роль должна простираться", пишет А. Даалдер в своей упоминавшейся вьше разработке. Союзники уже согласились, что на Балканы прерогативы альянса должны распространяться. Не без юмора С.Тэлботт в одном из недавних выступлений однако заметил, что в НАТО никто не предлагает размещать силы НАТО, например, на островах Спратли.

Говоря o deeping of NATO, он вместе с тем отрицал, что расширение пространственной сферы действия альянса, как и наделение его прерогативой применять вооруженную силу вне рамок ст. 5 Вашингтонского договора, требует 
его пересмотра. По его словам, создатели этого договора “были достаточно осмотрительны, чтобы не налагать произвольных функциональньх или географических ограничений на то, что аљянс мог бы делать для защиты своей безопасности". Мы нуждаемся в силах, доктринах и коммуникационных средствах, позволяющих нам, когда необходимо, ответить на вызовы этнической борьбы и региональньх конфликтов, продолжал Тэлбот, - "которые затрагивают нашу безопасность, но находятся за пределами территории НАТО”.

Весьма показательно, что анализу тех положений проекта стратегической концепции, которые посвящены расширению радиуса действия НАТО, Б. Симма предпослал заголовок “Вне района или вне договора?”, в котором в частности упомянул мнение одного из членов Конституционного суда ФРГ о Вашингтонском дотоворе, как о "договоре на колесах".

Однако такого рода подвижность этого договора, вернее границ его действия означает не что иное как некую попытку эвентуально распространить его действия на третьи, не участвующие в нем государства, создавая положение, в котором для них возникали бы некие обязательства по отношению к НАТО. В известной Венской конвенции о праве договоров 1969 г. на этот счет предусматривается ряд критериев, которые игнорируются в Концепции: требуется, чтобы обязательство для третьего, т.е. не участвующего, посударства возникло "из положения договора", и чтобы “именно это положение" участники договора имели "намерение сделать" "средством создания обязательства". Никаких положений такого рода в договоре НАТО нет, и ни одно из положений Стратегической концепции - недоговорного документа не может явиться их заменителем. А главное состоит в том, что согласно Венской конвенции обязательство цля государства из договора, в котором оно не участвует, возникает лишь в том случае, если оно "определенно принимает на себя это обязательство в письменной форме". Не приходится и говорить, что ни от одного из государств, которые может иметь в виду НАТО, подобного рода принятия натовских "благодеяний", тем более в письменной форме, не последовало, не говоря уже о том, что сами члены НАТО отнюдь не едины в том, что касается расширения географической сферы альянса. Не случайно накануне саммита Даалдер писал, что союзникам "следует общим образом ограничить географическую сферу досягаемости НАТО, в том числе в отношении утрозы и применения силы, Европатлантическим регионом. В то же время им не следует делать ничего, что отнимало бы у тех союзников, которые этого желают, возможность действовать за пределами этого региона, если и когда они считают это необходимьм. По его мнению, одна из уникальньх сиљьньх сторон атьянса состоит в том, что он обеспечивает солидную основу для военньх акций некоторьх или всех союзников "в защиту их территории, ценностей и интересов, где бы проведение такого рода акций они не сочли бы уместньми".

Именно такой подход и санкционирует стратегическая концепция НАТО, не считаясь не только с постулатами международного права, но и с положениями Вашингтонского договора.

5. НАТО и Совет Безопасности ООН.

В Стратегической концепции встречаются скупые ссылки на ООН и ее роль, в том числе в европейских делах, упоминается о некоторьх нормах ее Устава и констатируется, что “Совет Безопасности ООН несет главную ответственность за поддержание международного мира и безопасности, занимая таким образом ключевую позицию в Евроатлантическом регионе”.

Эта декларируемая, и при том чисто формально, полуприверженность отдельным положениям Устава ООН - обращает на себя внимание, что не говорится о приверженности целям и принциам ООН - перекрывается нагнетаемыми в Концепции притязаниями НАТО на некое верховенство в международньг делах и на фактическое оттеснение Совета Безопасности и ООН в целом, всей 
нормативной системы в сфере поддержания мира и безопасности, воплощенной в Уставе, на задний план. Даже уставное положение о главной ответственности Совета Безопасности воспроизведено в Концепции таким образом, что оно оказалось вырванным из контекста друтих положений Устава о роли и месте Совета, в том числе норм, касающихся его прерогатив, имеющих прямое отношение к деятельности таких организаций, как НАТО.

Весьма характерно, что в Концепции, как это имело место и ранее, не признается, что НАТО является региональной организацией. НАТО явно не желает сообразоваться с теми нормативами, которые заложены в Уставе применительно к региональным организациям и их военно-силовой деятельности. Главные из этих нормативов состоят в том, что Совет Безопасности использует, где это уместно, региональные органы для принудительных действий "под его руководством"; что “никакие принудительные действия не предпринимаются" в силу регионаљьнхх соглашений "без полномочий от Совета Безопасности" (ст. 53) и что Совет "догжен быть всегда полностью информирован о действиях", как предпринятьх, так и намечаемых в такого рода региональном порядке (ст. 54). Эти положения Устава обеспечивают возможность необходимого политико-правового контроля со стороны Совета Безопасности за военно-силовой деятельностью региональньх организаций, что особенно существенно в постконфронтационном мире, в котором, наряду с локальными и внутренними, на первый план все больше выдвигаются региональные конфликты.

Именно в стремлении уйти от такото контроля со стороны ООН, НАТО, как правило, отқрещивается от амплуа регионаґной организации. Об этом, в частности сказано в письме Генеральному секретарю ООН предшественником Х.Соланы на посту Генераљього секретаря НАТО В. Клаасом, и это подчеркивается в западной доктрине международного права даже теми юристами, которые не разделяют линию альянса на его особую роль и место в современном международном правопорядке: "НАТО не является регионашьой орғанизацией в смысле главы VII Устава ООН", поэтому ст. 53 этой гјавы “формально не применима в случае НАTO”.

Мотивировка отторжения региональности НАТО нередко дается весьма откровенная: В Совете Безопасности правом “вето" пользуется, как и другие постоянные члены Россия, и применив его в отношении какого-либо принимаемого им решения, касающегося альянса, Россия тем самым косвенно наложнла бы "вето" на предусматриваемую в решении акцию самой НАТО, что для ее членов принципиаљно неприемлемо.

По укоренившимся на Западе представлениям, НАТО является не регионаљьной организацией, а организацией каплективной обороны, основывающейся на ст. 51 Устава ООН. Но юридической необоснованности притязаний алъянса это не устраняет: поскальку принятием Стратегической концепции НАТО закреплет распространение сферы своего военного активизма за рамки статьи 5 своего договора, предусматривающей коллективную самооборону, на военные ахции апянса вне рамок этой статьи не может не распространяться запрещение применения силы, предусмотренное друтими нормами Устава, о которьх говорилось выше, так как согласно статьи 103 в случае, когда обязательства по международному договору оказываются в противоречии с обязательтвами по Уставу, “преимущественную силу", как уже указывалось, имеют обязательства по Уставу.

Такова принципиаљно-правовая сторона дела. Но есть и практическая. За последние пять лет отношения НАТО и ООН эволюционировали не в польз ООН.

На своем саммите в Брюсселе в 1994 г. альянс заявил о готовности сотрудничать с ООН в операциях по поддержанию мира "и других операциях под руководством Совета Безопасности ООН", что отвечало требованиям ст. 53 Устава.

Позднее на одном из форумов, проходившем под эгидой НАТО, еще выражалось сомнение, что альянс пойдет на применение принудительньх мер, по 
крайней мере, за пределами района своего действия, “без полномочий от Совета Безопасности”. В течение менее, чем года сомнения рассеялись. Как обоснованно считает Б. Симма, действия НАТО сдвинулись от полного сотрудничества с ООН в области операций по поддержанию мира и в отношении применения принудительньх мер в Боснии, к принудительным действиям "вместо ООН, еще разрешенным Советом Безопасности", для имплементации Дейтонских соглашений, а теперь в когтексте Косово - “к принудительным действиям вместо ООН без такого разрешения. При такой эволюции - взаимоотношениям НАТО и Совета Безопасности Организации Объединенньх Наций угрожает "соскальзывание в ненужность", а Совет Безопасности "рискует исчезнуть как серьезный орган безопасности”. Все, что он может предоставить, по мнению некоторьх западньх кругов - это легитимация, тогда как НАТО может обеспечить необходимое “многостороннее прикрытие”.

При всем этом практика недавних лет показывает, что в условиях доминирующего в политике НАТО стремления отмежевываться от амплуа региональной организации и от политико-правовых ограничений на ее военно-силовые акции, все же в ряде случаев альянс был вынужден идти на то, чтобы его в Совете Безопасности трактовали как региональную организацию. В частности, это имело место в резолюции Совета 1031 (1996 г.), касающейся Дейтонских соглашений по урегулированию в Боснии, да и в самом Соглашении о военньх аспектах урегулирования. В этом соглашении НАТО прямо названа, региональной организацией, и именно в этом качестве была уполномочена Советом на обеспечение выпопнения соглашения.

Таким образом, когда альянсу выгодно и угодно, он соглашается на амплуа региональной организации, когда нет - открещивается от этого амглуа. Но такая дво̆йственность является аномалией: или НАТО признает за собой качество региональной организации или атянс, не признавая этого качества, догкен рассматриваться в международном правопорядке как аутсайдер, как некая правовая аномалия, паразитирующая на игнорировании международного правопорядка.

Уже цитировавшаяся выше статья 103 Устава ООН о преимущественной силе обязательств ее членов по Уставу, лишает правовой обоснованности как стремление НАТО не считать себя региональной организацией, так и попьтки альянса возвести в принцип возможность прибегать к вооруженным акциям без мандата от Совета Безопасности ООН, как это просматривается в Стратегической концепции и в ее интерпретации, в особенности в кругах США и самого НАТО. В частности, С. Тэлботт, оговорившись, что НАТО и ее члены будут продолжать руководствоваться свонми обязательствами по Уставу ООН и Хельсинкскому акту; подчеркнул в одном из своих выступлений, что не следует "подчинять НАТО какому-либо другому международному органу" и что альянс дольен резервировать за собой “право и свободу действовать, когда ее члены консенсусом считают это необходимым".

Сторонником такой свободы действий альянса является и Генеральньй секретарь НАТО, утверждавший, что "НАТО должна иметь возможность, от случая к стучаю, действовать, если необходимо, по собственному решению” и что вообще могут быть обстоятельства, в которьх требуется действовать "из гуманитарньх соображений, когда резолюция Совета Безопасности "не будет необходимой или даже уместной".

В этой связи, давая оценку доводам Соланы, что НАТО - это все-таки серьезная организация, которая принимает решения путем консенсуса между серьезными странами с демократическими правительствами Б. Симма не без оснований заметил, что никакое единогласие государств-членов НАТО не может устранить границы, с которыми эти государства должны сообразоваться в ситу существуюших в международном праве норм jus cogens, в особенности в отноше- 
нии неприменения силы, как эти нормы выражены “в высшем праве Устава OOH'.

В порядке поиска вьхода из ситуации весьма острой коллизии с Уставом ООН, в которую НАТО ставит себя своим игнорированием Совета Безопасности, в кругах западньх международников выдвигается идея о том, что санкцию Совета Безопасности на осуществление военных мер против государства такие организации как НАТО долокны иметь “как правило". К сожалению, против искушения соблазниться этой идеей не устоял и Генеральный секретарь ООН К. Аннан. Когда на пресс-конференции в Брюсселе в январе с.г., после посещения им штаб-квартиры НАТО, его спросили о том, что потребуется для действий НАТО в СРЮ, он ответил: "Нормально требуется резолюция Совета Безоласности", допуская тем самым возможность действий НАТО и без такой резолюции.

Объективно такие допущения исключения, как и утверждение о том, что военная акция против Ютославии без санкции Совета Безопасности, не создает прецедента, служат выгораживанию НАТО. В сущности это работает в том же направленин, что и натовская теория самоуполномочивания (self-authorization) на военно-принудительные меры против других государств, которая является еще одним показателем того, что новая стратегическая концепция НАТО, помимо ущербности своих военно-политических установок, является еще и концепцией игнорирования целого ряда ключевьх норм международного права, что, конечно, не предвещает для НАТО перспективного будущего.

Насколько юридически несостоятельным является подобное самоуполномочивание со стороны альянса, со всей очевидностью показывает его уже упоминавшееся притязание на противодействия по своей линии в т.ч. и вооруженной силой, без санкции Совета Безопасности, распространению ядерного и другого ОМУ. Хорошо известно, что основополагающие международные акты в этой области и прежде всего Договор о нераспространении ядерного оружия и Договор о всеобъемлющем запрещении ядерных испьтаний предусматривают вовлеченность Совета Безопасности в тахого рода противодействие - в оговоренньх договорами обстоятельствах. Если теперь НАТО, исходя из Стратегической концепции, собирается боротъся с распространением ОМУ по собственному усмотрению, вплоть до игнорирования зафиксированньх в договорах функций Совета Безопасности, то это не может не означать, что Аљянс не намерен останавливаться и перед нарушением названньх важнейших договоров в части, касающейся предусмотренных в них прерогатив Совета Безопасности.

Поистине, в ряде положений своей новой стратегической концепции Альянс оказался на крутом склоне и начал скользить в состояние беззакония. И этому не помогут никакие попьтки проводить близкое к расщеплению волоса различие междy legally and legitimately.

Как считает ряд аналитиков на Западе, если альянс сделает нарушения Устава ООН "регулярной частью своей стратегической программы на будущее”, это окажет "деструктивное воздействие на всю универсальную систему коллективной безопасности, заложенную в Уставе ООН". И далее: если договор НАТО и может иметь “прочный правовой стержень”, который даже самая кнновационная интерпретация не сможет подвергнуть эрозии, то "это подчинение НАТО принципам Устава Организации Объединенных Наций”. Нного выбора у НАТО нет.

6. Ютославский аспект посягательств НАТО на международный правопорядок.

Военная акция НАТО против Югославии, предпринятая за месяц до утверждения альянсом новой Стратегической концепции, с самого начала сопровождалась попытками придать ей видимость обоснованности с точки зрения и более специфических положений международного права.

В заявлении, сделанном в ночь на 23 марта с.г., руководство НАТО, сообщая об акции, признало: “Мы хотим тем самьм поддержать международные усилия 
по обеспечению согласия Югославии на промежуточное политическое урегулирование". Иначе говоря в качестве одного из мотивов военной акции было объявлено намерение вынудить Югославию дать согласие на подписание нужного НАТО имглементационного соглашения, говоря языком международного права, согласиться на заключение договора под военным давлением. Гитлер в Мюнхене в 1938 г. дальше угроз не зашел, хотя его войска концентрировались на границе с Чехословакией; НАТО свою угрозу реализовало.

Известен и получил дољжное отражение в международном праве эпилог мюнхенского диктата.

Разрабатывая в 1968-1969 гт. Венскую конвенцию о праве договоров, представительная Конференция ООН приняла специальную Декларацию, в которой говорится, что Конференция "торжественно осуждает обращение к утрозе или к применению всех форм какого бы то н и было давления, военного, политического иши экономического, каким бы то ни было государством с целью принуждения другого государства совершить какой-либо акт, связанный с закпючением договора в нарушение принципа суверенного равенства государств и свободы согласия".

В принятой на конференции Конвенции о праве договоров предусматривается, что недопустимо принуждать государство к заключению договора посредством угрозы силой или ее применения. "Договор является ничтожным, если его заключение вилось результатом утрозы силой ити ее применения в нарушение принципов международного права, воплощенньх в Уставе ООН", подчеркивается в конвенции.

И если НАТО отказывается прекратить бомбардировки и в то же время настаивает, чтобы Югославия пошла на закпючение угодного альяну соглашения, то ашянс совершает двойное нарушение международного права: а) итнорирует запрет на оказание военного давления с целью навязывания договора; б) пытается подменить договоренность об урегулировании конфликта заведомо недействительным, ничтожным с точки зрения международного права, соглашением.

Не в ладах НАТО с международным правом и тогда, когда пытается заострить против Югославии Конвенцию о предупреждении геноцида и наказании за него 1948 r.

В этой Конвенции ни слова не говорится о возможности применения военньх мер для обеспечения ее соблюдения государствами либо для воздействия на те из них, которые нарушили бы ее положения.

Ее существо и смысл предусмотренных в ней мер тақовы, что ответственность за ее нарушения осуществляются только в судебном порядке, через использование национальньх и международньх судебньх процедур.

В свете этого предстают как более чем произвольные действия НАТО, по существу пытающейся усвоить роль некоего судьи над Югославией, взяв правосудие, так сказать, в свои руки, и одновременно с этим выступить в роли судебного исполнителя - с военным обухом. И в этом случае вновь игнорируется право - известный издавна принцип Ex injuria jus non oritur - из бесправия не возникает права.

Предъявляя Югославии обвинение в нарушении Конвенции о геноциде, а установить это может только суд - ведущим натовцам следовало бы сверить с конвенцией свое собственное поведение. Ках известно, Конвенщия о геноциде не только предусматривает ответственность индивидов за это преступление, но и говорит об ответственности государства за совершение геноцида. В статье IX Конвенции, где речь идет о разрешении Международным судом споров относительно конвенции, в числе вопросов, которые подлежат такого рода урегулированию судом, указаны толкование, применение или выпюлнение конвенции, причем специально оговаривается: “включая споры относительно ответственности того или другого государства за совершение геноцида".

Из этого положения с непреложностью следует, что, считая СРЮ ответст- 
венной за несоблюдение Конвенции о геноциде, США располагают основанным на Конвенции способом разрешения создавшейся проблемы - возможностью обращения в Международный суд. Прибегнув вместо этого к военной акции, США и страны НАТО показали, что метод решения вопроса с использованием правового инструментария, тем более такого как Международный суд, они игнорируют. Но это лишь подчеркивает международную противозаконность предпринятой ими военной акции.

Возвращаясь к ссылкам США на эту конвенцию, приходится констатировать, что они проитнорировали еще одно ее положение. Сопласно статье VIII каждое участвующее в Конвенции государство “может обратиться к соответствующему органу” ОOH "с требованием гринять в соответствии с положением Устава" "все необходимые, по его мнению, меры в целях предупреждения и пресечения актов геноцида".

Таким образом, Конвенция о геноциде не оставляет сомнений в том, что для того, чтобы побуждать к ее соблюдению, допустимы и правомерны отнюдь не односторонние, тем более военные меры, а обращение к предусмотренным конвенцией международньм механизмам.

В арсенале самооправданий альянса занимает место также его утверждение, что "НАТО не ведет войну против Югославии".

Характер наносимьд военньх ударов по этой стране опровергает эти утверждения, как и рассуждения о том, что НАТО своей военной акцией якобы не преследуют цели посягательства на территориальную неприкосновенность или политическую независимость Югославии.

Несостоятельны попытки представить дело так, что якобы нет поэтому и нарушения принципа неприменения силы, предусмотренного соответствующим положением Устава ООН. Как указывается в Докладе Генерального секретаря ООН по вопросу об определении агрессии, представленном в свое время ООН, “им (т.е. этим положением), запрещается не только война как таковая, но также и применение силы, хотя возможно утверждать, что применение силы не создает войны или желания прибегнуть к войне".

В докладе поясняется, что имеющиеся в Уставе слова "как против неприкосновенности или политической независимости любого государства" были включены "в твердом намерении обеспечить соблюдение территориальной неприкосновенности и политической независимости государства, а не для того, чтобы в некоторьх случаях можно было прибегать к угрозе силой или ее применению".

Военная акция НАТО против СРЮ высвечивает в целом двойственное отношение НАТО к правовым основам современного мироустройства. С одной стороны, там, где это им вьгодно, натовцы пытаются опереться хотя бы на какую-либо из этих основ. С другой, дело изображается таким образом, что многие международные принципы и нормы это не балее, чем реликты якобы уходящего миропорядка, которые требуют некоего переосмысливания, переоценки, и заниматься этим надо не иначе как под свист натовских бомб и грохот взрывающихся ракет.

Нельзя, конечно, не отдавать отчет в том, что рассуждая, во многом на официальном уровне, о формировании новой международно-правовой доктрины и ставя под вопрос некоторые основополагающие принципы международного права, адвокаты натовской воинственности делают своей мишенью весь международный правопорядок в целом, рассчитывая на подмену его другим, угодным им регулированием, стержнем которого был бы натоцентризм, культ силы. Но тогда закономерно встает вопрос о том, что им становится неугодным Устав ООН, это концентрированное выражение современного правопорядка, с основанной на нем обширной и многообразной системой международньх соглашений, решений, урегулирований, договоренностей и т.п. Бесценна для человечества уже сама по себе эта ткань координирующих, регулирующих, охраняющих, а, когда необходимо и запрещающих установлений. Непреходящую ценность имеет и 
сущностное содержание тех норм межгосударственного общения, которые они воплощают. Истина конкретна.

Если оттесняется на задний план существующий правопорядок, основанный на Уставе ООН, то это значит, что:

- попирается решимость народов избавить нынешнее и грядущие поколения людей от бедствий войны, как эта решимость выражена в Уставе;

- подавляется их законное стремление проявлть терпимость жить вместе, в мире друг с другом, как добрые соседи;

- парализуются усилия государств и народов разрешать возникаюшие проблемы таким образом, чтобы не подвергать утрозе мир, безопасность и справедливость;

- подрывается закрепленная в Уставе ООН их твердая воля обеспечить "чтобы вооруженные силы применялись не иначе, как в общих интересах”, именно в общих, а не в блоковьх интересах;

- развенчивается потребность в том, чтобы непрерывно воссоздавать условия, при которьх могли бы соблюдаться обязательства по международному праву;

- игнорируется право человека на жизнь, и вообще на международный порядок, при котором его права и свободы могли бы полностыю осуцествцяться.

Все зто отнюдь не отвлеченные идеалы, не чисто доктринальные постулаты, а реальные непреходящие устои современного международного правопорядка, его неотьемлемые компоненты и основные цивилизационные грани, опрокинуть которые хотели бы адвокаты натовских военньх авантюр.

Но современный международный правопорядок - это не предмет для произвольньх манипуляций. Это объективно существующий порядок отношений между участвующими в них государствами и другими действующими лищами, который сложился в итоге длительного неоднозначного опыта межгосударственног̈о общения, непростых процессов формирования и применения общепризнанных норм международного права. Их нарушения, даже тягчайшие - и об этом свидетельствуют политико-правовые итоги второй мировой войны - не в состоянии свести на нет ни сам международный правопорядок, ни его общественноисторическую обусловленность, равно как и необходимость в его даљьейшем совершенствовании. Военные акции НАТО рано или поздно исчерпают себя, жизнь, международное общение будет продолжаться, вновь в должной мере международной правопорядок будет функционировать.

Нельзя вместе с тем отвлекаться и от того, что силовое "переосмысливание" международного правопорядка сопровождается все увеличивающимся числом людских жертв в Югославии, превращением в руины ее городов, страданиями сотен тысяч беженцев. И это может стать уделом других стран и народов, если попытки натовских ниспровергателей международного правопорядка не будут обращены вспять.

Дело, конечно, не только в Ютославии, а ранее в Боснии. И тут, и там явно отрабатывается модель военного давления на государства, которые могут попасть или попали в конфликтную ситуацию в мирное время, и вообще один из сценариев реального военного доминирования на континенте. Как выразился английский аналитик на симпозиуме, посвященном роли НАТО в боснийском урегулировании, миссия СВС "снабдила Альянс моделью для будущих многонациональньх развертываний от среднего до широкого масштаба". (N.Figa Talamanca.. The Role of NATO in the Peace Agreement for Bosnia and Herzegovina. “European Journal of International Law”, vol. 7, N 2, 1996, p. 165).

На противодействие реализации такой модели догжны быть направлены все возможности и средства современного международного правопоряцка. 
Профессор В.П. Пархитько.

Нападение НАТО на Югославию, открытте бомбежки самогетами США, Англии и некоторых других стран, входящих в НАТО, являют собой не только акт агрессии со стороны международной организации, но и действия, представляющие собой международный терроризм, опять-таки впервые в истории международньх отношений осуществлемый со стороны международной организации.

В этом особенность этого действия НАТО - агрессия и международный терроризм. Это, - если расценивать эти действия с точки зрения постулатов существующего международного права, о которых говорил В.А. Романов.

В создавшейся обстановке хотел бы обратить внимание на весьма примечательную параллель. Сто лет назад, перед созывом Первой Гаагской конференции мира, рухнула старая Вестфальская система, и мир заговорил о необходимости создания новой системы международных отношений, в которой участвовали бы все "цивилизованные" страны мира. Таких стран тогда насчитали 26, и все они приняли участие в конференции в Гааге в 1899 году. Впервые на международную конференцию прибыли представители стран из Европы и Азии, Америки и Африки, даже из Австралии.

Сейчас таким представительством никого не удивишь. Удивляет другое: одна страна так ловко научилась манипулировать своими союзниками, что каждый из них - по тем или иным причинам - разделяет мнение США, голосует в международной организации так, как будет угодно США. И получается volens-nolens, - что США навязывают многим остальным странам свое мнение.

Вот и получается, что главным в доктрине НАТО прописан не "мир во всем мире", а "защита интересов стран-членов НАТО" во всем мире.

Можно ли в этих условиях что-то противопоставить этой безумной военной доктрине, позволяющей посылать бомбардировщики в любую точку мира, где "задеты интересы НАТО"? Конечно, можно.

Эту формулу нашел академик Евгений Максимович Примаков. Это - идея "многополярного" или как его еще называют иначе "многополюсного мира". Идея овладела руководством многих весьма уважаемых государств: о ней с удовлетворенностью говорят в Китае, Индии, Индонезии, Бразилии и ряде других важньх и крупных государств.

Речь идет не только о том, чтобы заставить охотников отречься от ООН действовать как раз наоборот и уважать эту организацию. Никто не собирается цепляться за все положения Устава ООН, считать незыблемыми его постулаты. Но действовать нужно только в рамках ООН, только придерживаясь норм и принципов, записанньгх в ее Уставе.

ООН - основа современного правопорядка. Нарушать ее принципы значит разрушать существующий правопорядок. XX век с его мировыми войнами, ядерными взрывами и полетами в космос отчетливо показал, что сила и будущее человечества покоятся только на переговорньх процессах, а бомбардировки типа натовских по Югославии - это путь в тупик, если не сказать еще резче, что будет справедливей.

\section{Профессор Ю.М. Колосов.}

В свете анализа стратегической концепции НАТО, проведенного профессором В.А. Романовым, этот альянс присваивает себе право вмешиваться во внутренние дела государств в случае проведения в них "неадекватных или неудачных попыток реформ. Это представляет собой вызов и угрозу государствам c переходной экономикой, а поэтому действия НАТО в Югославии могут рассматриваться как некий тренировочный полигон.

K сожалению, все эти события, нарушающие сложившийся мировой право- 
порядок, происходят в последний год провозглашенного ООН Десятилетия международного права. Поэтому действия НАТО следует расценивать и как вызов всему международному сообшеству.

В мае-июне отмечается 100-летие Первой конференции мира, состоявшейся в 1899 г. в Гааге по инициативе России. НАТО нарушает принятые на ней нормы межпународного гуманитарного права, нанося бомбовые удары по незащищенным гражданским объектам.

Есть в этом вопросе и морапьная сторона. В 1928 году был принят Парижский пакт об отказе от войны в качестве орудия национальной политики. Пакт остается в силе и по сей день. Инициаторами его принятия были Бриан (Франция) и Келлог (США). Ести США и Франция считают "гуманитарную интервенцию" своей национальной политикой, то в свете Пакта Бриана-Келлога она не дагжна осуществлятъся с помощью даже “необъявленной войны”. Предание забвению инициативы собственньх сограждан явљяется, помимо прочего актом аморальным.

\section{Профессор П.В. Саваськов.}

Действия НАТО в отношении Сербии показывают, что современное международное право не просто переживает трудный период. Попраны основополагающие принципы международного права: запрет применения силы или ее угрозы, невмешательства во внутренние дела, добросовестного соблюдения международньх обязательств.

Вооруженный конфликт развязали члены ООН, из которьх три государства - постоянные члены Совета Безопасности. Применение вооруженной силы вопреки положениям Устава ООН явцется нарушением не только уставньх обязательств, но и обязательств, предусмотренных общим международным правом. Подобные нарушения подрывают не просто основы международного права. Они подрывают веру международного сообщества в международное право.

Между тем обрашение ряда государств-членов НАТО к вооруженной силе не является случайным. Тақ, Соединенњые Штаты Америки не раз после Второй мировой войны использовали свои вооруженные силы шця вмешательства во внутренние дела друтих посударств. Внимание международного сообщества отвлекалось на действия СССР и его союзников, в частности на вмешательство СССР и его союзников во внутренние дела Венгрии в 1956 г. и во внутренние дела Чехословакии в 1968 г., на противоправный ввод Советским Союзом вооруженньх сил в Афганистан. А противоправные действия США, между тем, не потучаши догжной международно-правовой оценки сообщества государств. В конечном счете, это не могло не сказаться и на отношении к международному праву.

Распад СССР нарушил равновесие сил, которое сложилось после Второй мировой войны, и ускорил развитие пренебрежительного отношения к международному праву. В частности, это проявилось и в виде образования Совета Безопасности ООН Международньх трибуналов для судебного преследования лиц, ответственньх за нарушения международного гуманитарного права, совершенные в бывшей Югославии и Руанде. Создав эти трибуналы, Совета Безопасности превысит полномочия, предусмотренные Уставом ООН. ООН либо ее органы могли бы создавать международные трибуналы, если бы это было предусмотрено ее Уставом либо она являлась наднациональной организацией.

Такие трибуналы могут создаваться в соответствии с современным международным правом только государствами, и юрисдикция таких трибуналов может распространяться лишь на государства, признавшие эту юрисдикщию. В связи с этим, на мой взгляд, одним из действенных шагов явилось бы внесение в ООН предложения о ликвидации названньх трибуналов. Ликвидация трибуналов могла бы только укрепить международное право. 


\section{Профессор Э.С. Кривчикова.}

Военные действия НАТО против Югославии и попытки оправдать подобные действия со стороны Американской ассоциации международного права, так и с позиций Устава ООН.

Современная система международного права, основанная на Уставе ООН подвергла радикальным изменениям “право войны", сложившееся в течение столетий. Государства не только отказались от войны как орудия национальной политики на основании Пакта Бриана - Келлога 1928 г., но и от угрозы силой или ее применения (любой силы и прежде всего вооруженной) на основе Устава ООН. Этот отказ не исключает правомерного применения силы в порядке индивидуальной или коллективной самообороны в случае вооруженного нападения одного государства на другое. При этом Устав допускает оборонительные вооружентые действия лишь до тех пор, пока Совет Безопасности не примет мер для поддержания или восстановления международного мира и безопасности.

Применение силы может иметь место также от имени ООН в случаях утрозы миру, нарушения мира и актов агрессии по решению Совета Безопасности и под его руководством. Это положение распространяется и на региональные организации, которые не вправе предпринимать принудительные действия без полномочий от Совета Безопасности. Эти краеугопьные положения современного международного правопорядка полностью нарушены США и их союзниками по НАТО.

Оценка подобного поведения может быть лишь одна "полное разрушение современной системы поддержания мира и безопасности на основе положений Устава ООН и реконструкция ряда старьх понятий, норм и принципов" существовавших в международном праве до первой мировой войны - т.н. классическом международном праве. Речь идет прежде всего в возврате к праву государств прибегать к силовым вооруженным действиям под предлогом защиты национальных интересов, интересов собственныг граждан и юридических лиц.

В принятой в апреле 1999 г., новой стратегической концепции НАТО, направленной на XXI век, НАТО наделяется правом применять военную силу без решения Совета Безопасности в самьг разньх ситуациях - противодействия оружию массового поражения, в случаях международного терроризма, распространения наркотиков и т.д. США и их союзники по НАТО идут к такому пониманию международного права целенаправленно. Об этом свидетельствуют действия США против Гренады, Панамы, Сомали, действия США и ряда государств НАТО против Ирака (начиная с “Бури в пустыне" и кончая "Лисой в пустыне") против боснийских сербов, а теперь и против Союзной Республики Югославия, включая территорию Косово. Надо подчеркнуть, что НАТО своими действиями против Югославии нарушили не только Устав ООН, но и положения собственного Северо-Атлантического договора.

В связи с вышесказанным возникает вопрос о международно-правовой ответственности как НАТО, так и государств-членов НАТО.

В современном международном праве признается правосубъектность международных организаций, а также их ответственность за нарушение ими международньх обязательств, вытекающих из договоров и других источников международного права. На любую международную организацию распространя. ется запрет прибегать к силе или к ее угрозе в обход и нарушение положений Устава ООН. Уже это позволяет поставить вопрос об ответственности НАТО и о ее роспуске. Постановку этого вопроса могла бы инициировать Россия на очередной сессии Генеральной Ассамблеи ООН. 
Резюме дискуссии подвел заведуюший кафедрой международного права, профессор Ю.М. Колосов.

Я считаю, что многократные устные выступления нашей страны против агрессии стран НАТО, которых было особенно много в конце марта - начале апреля (то есть в начале конфликта) должны были подтверждаться конкретными действиями. Так как действия стран НАТО нельзя было рассматривать иначе, нежели как агрессию в отношении суверенного государства, Россия, как мне кажется, имела право, допустим, направить в район Адриатики - $\mathbf{K}$ берегам Югославии усиленную морскую эскадру, состоящую из кораблей Северного флота, или совершить пролет военньх воздушньг судов (конечно, в пределах воздушного пространства над открытым морем) в районе границ некоторьдх стран НАТО (напрнмер, Германии и Польши). Такая демонстрация силы, возможно имела бы определенный эффект и заставил бы обе стороны сесть за стол переговоров, особенно, учитывая силу резонанса, вызванного никем не подтвержденной информацией о перенацеливании российских ядерньх ракет на объекты в странах НАТО. По-видимому, этого не было сделано из-за крайне тяжелого финансового и материально-технического состояния российских вооруженньх сил в настоящий момент. Учитывая данный фактор, направление в район Адриатики одного небольшого разведывательного корабля стало фарсом (эта “демонстрация силы” напоминает басню Крылова о маленькой собачке Моське, лающей на слона). Я считаю, что такие ничем не подтверждаемые "грозные окрики" со стороны России ведут к снижению нашего и без того уже незначительного авторитета на международной арене. С моей точки зрения грубейшей ошибкой было также попустительство в отношении созыва заседания Совета Безопасности ООН - у России было почти 24 часа для того, чтобы это сделать (я имею в виду период с момента объявления Генеральным Секретарем НАТО о принятии решения о бомбардировках до отдачи приказа о начале военньх действий). Даже, если документы, регламентирующие порядок работы такого органа и не позволяют этого сделать в такие короткие сроки, я думаю, что в данном случае все государства-члены СБ согласились бы сделать исключение, учитывая то, что бомбардировки территории Югославии без санкции СБ ООН тоже в настоящий момент часто называются "исключением".

Говоря о настоящем моменте (конец мая) я считаю необходимым немедленно прекратить переговоры, ведушиеся специальным представителем Президента РФ Черномырдиным В.С., так как они уже на протяжении более чем двух недель не приносят никаких результатов. Они способствуют "затуманиванию" - создается впечатление о том, что ведется серьезная работа и вскоре все успешно завершится, на самом же деле ни одна из сторон в конфликте до сих пор не может сдвинуться с мертвой точки.

Материал поступил в редакцию в мае 1999 г. 